From the Serological Laboratory of the Office of the Chief Medical Examiner of New York City, and the Division of the Immunohematology of the Jewish Hospital of Brooklyn

\title{
STUDIES ON THE HEREDITY OF THE HUMAN BLOOD GROUPS. I. THE M-N TYPES ${ }^{1}$
}

\author{
by \\ A. S. Wiener, N. Di Diego and S. Sokol
}

The use of blood grouping tests in cases of disputed paternity is now so commonplace in courts of law, that the results of such blood tests are generally accepted at face value (Schatkin, 1953; Lombard, 1952; Unger, 1953). This may be attributed largely to the greatly increased interest in blood group research which followed the discovery of the Rh-Hr blood types. Recently, a report (Davidsohn, Levine and Wiener, 1952) has been published summarizing the present status of the medicolegal aspects of blood grouping tests.

As a result of the increased intensity of research in the field of blood grouping, many new blood factors have been discovered (Race and Sanger, 1951). Unfortunately, there has been a tendency among certain workers to apply newly discovered factors in medicolegal cases prematurely. Before a blood factor is ready for practical application, extensive investigations on its serology and genetics are needed in order to establish the dependability of the test. In some cases the technique itself of determining the blood factor is not entirely reliable; e. g., in the case of the Kell and Duffy factors one must resort to the ticklish anti-globulin or conglutination methods, both of which have numerous pitfalls. In addition, for certain blood factors the only antisera available are of low specificity, avidity or titer. For the newer blood factors, moreover, not enough studies have been carried out to establish with certainty the mechanism of transmission. The premature application of such tests is bound to lead to mistakes which may tend to discredit the entire subject.

The purpose of the present series of papers is to summarize the investigations carried out in this laboratory during the past three decades on the heredity of the human blood group factors and to present new data previously not reported. We shall also indicate which blood group factors, in our opinion, can be applied reliably in medicolegal cases, and for which blood factors further research is essential before they can safely be used.

1 The authors wish to express their appreciation to Miss Nancy Ercolono for her assistance in making the statistical analysis of the data presented here. 
The judicious application of blood grouping tests in courts of law will thus serve to prevent miscarriage of justice, and will stimulate jurists to resort to the use of blood tests more frequently.

\section{Materials and Methods}

In our first investigation (Wiener and Vaisberg, 1931) more than two decades ago it was necessary to visit the homes of dispensary patients in order to obtain material for genetic studies. In recent years the collection of such material has been greatly simplified as a result of the routine application of antenatal $\mathrm{Rh}-\mathrm{Hr}$ blood typing and antibody titrations for the diagnosis of erythroblastosis in the unborn baby. Hundreds of families have thus become available for blood group investigations. Accordingly, in recent years our material has been compiled almost exclusively from private patients, and the disturbing problem of illegitimacy only rarely enters to complicate the interpretation of the results.

In the present series of papers we shall summarize material accumulated during the years 1949-1952. The technique of the test has been described in detail in previous publications (Wiener, 1943) and need not be repeated here. To save space a detailed list of the families will not be published, although this has been our custom in previous reports. However, selected families will be described in detail whenever this is necessary in order to illustrate problems of special interest. The present paper will be limited to an analysis of the results of M-N tests.

\section{Results}

In table 1 is given a summary of the results of the M-N tests in 420 families, tested during the years 1949 to 1952 . As the table shows, there is not a single exception to Landsteiner and Levine's (1928) theory of heredity of the M-N types. For example, in the mating $M \times M$, all 54 children belong to type $M$; in the mating $M \times N$, all 61 children belong to type $\mathrm{MN}$, while in the mating $\mathrm{N} \times \mathrm{N}$, all 34 children belong to type $\mathrm{N}$. In the mating $\mathrm{MN} \times \mathrm{M}, 91$ children belong to type $\mathrm{M}$ and 86 to type $\mathrm{MN}$, which agrees satisfactorily with the theoretical expectation of 50 percent each of these types; and similar results were obtained in the mating $M N \times N$. In the mating $M N \times M N$, there were 36 children of type $\mathrm{M}, 36$ of type $\mathrm{N}$, and 88 of type $\mathrm{MN}$, a satisfactory approximation to the expected ratio $1: 1: 2$.

In table 2 we have combined the results of the present study with the results of our previous investigations (Wiener, 1951). As can be seen, to date we have tested 1580 families with 3379 children for the M-N types. There are six contradictions to the genetic theory of Landsteiner and Levine. However, these seeming exceptions all came from our earlier investigations, and have been shown to be due to illegitimacy. For example, in five cases the supposed father was excluded either because he belonged to type $M$ and the child to type $N$, or he belonged to type $N$ and the child to type $M$. Significantly, there are no such contradictions involving a mother. Moreover, in a series of more then 2,000 cases of disputed paternity (Wiener, 1950) not once have we encountered a type $M$ mother with a type $N$ child, nor a type $N$ mother with a type $M$ child. 
A. S. Wiener, N. Di Diego and S. Sokol: Studies on the Heredity etc.

Table I. Heredity studies on the M-N types (1949-1952)

\begin{tabular}{|c|c|c|c|c|c|c|}
\hline \multirow{2}{*}{$\begin{array}{l}\text { Parental } \\
\text { combination }\end{array}$} & \multirow{2}{*}{$\begin{array}{l}\text { Number } \\
\text { of families }\end{array}$} & & \multicolumn{3}{|c|}{ Children belonging to type } & \multirow{2}{*}{ Total } \\
\hline & & & $M$ & $\mathrm{~N}$ & MN & \\
\hline$M \times M$ & 3.4 & $\begin{array}{l}\text { Number } \\
\text { Per cent }\end{array}$ & $\begin{array}{c}54 \\
100.0\end{array}$ & $\begin{array}{l}0 \\
0\end{array}$ & $\begin{array}{l}0 \\
0\end{array}$ & 54 \\
\hline $\mathrm{M} \times \mathrm{N}$ & 37 & $\begin{array}{l}\text { Number } \\
\text { Per cen: }\end{array}$ & $\begin{array}{l}0 \\
0\end{array}$ & $\begin{array}{l}0 \\
0\end{array}$ & $\begin{array}{c}61 \\
100.0\end{array}$ & 61 \\
\hline $\mathrm{N} \times \mathrm{N}$ & 24 & $\begin{array}{l}\text { Number } \\
\text { Per cent }\end{array}$ & $\begin{array}{l}0 \\
0\end{array}$ & $\begin{array}{c}34 \\
1.00 .0\end{array}$ & $\begin{array}{l}0 \\
0\end{array}$ & 34 \\
\hline $\mathrm{MN} \times \mathbf{M}$ & 122 & $\begin{array}{l}\text { Number } \\
\text { Per cent }\end{array}$ & $\begin{array}{c}91 \\
51.4=2=2.4\end{array}$ & $\begin{array}{l}0 \\
0\end{array}$ & $\begin{array}{c}86 \\
48.6 \pm 2.4\end{array}$ & 177 \\
\hline $\mathrm{MN} \times \mathrm{N}$ & 101 & $\begin{array}{l}\text { Number } \\
\text { Per cent }\end{array}$ & $\begin{array}{l}0 \\
0\end{array}$ & $\begin{array}{c}82 \\
51.6 \pm 2.7\end{array}$ & $\begin{array}{c}77 \\
48.4 \stackrel{2.7}{=}\end{array}$ & 159 \\
\hline $\mathrm{MN} \times \mathrm{MN}$ & 102 & $\begin{array}{l}\text { Number } \\
\text { Number }\end{array}$ & $\begin{array}{c}36 \\
22.5 \pm 3.0\end{array}$ & $\begin{array}{c}36 \\
22.5 \pm 3.0\end{array}$ & $\begin{array}{c}88 \\
55.0 \pm 2.6\end{array}$ & 160 \\
\hline Totals & 420 & & 181 & 152 & 312 & 645 \\
\hline
\end{tabular}

Table 2. Heredity studies on the M-N types (1929-1952)*

\begin{tabular}{|c|c|c|c|c|c|c|}
\hline \multirow{2}{*}{$\begin{array}{c}\text { Parental } \\
\text { combination }\end{array}$} & \multirow{2}{*}{$\begin{array}{c}\text { Number } \\
\text { of families }\end{array}$} & & \multicolumn{3}{|c|}{ Children belonging to type } & \multirow{2}{*}{ Total } \\
\hline & & & M & $\mathbf{N}$ & $\mathrm{MN}$ & \\
\hline $\mathrm{M} \times \mathbf{M}$ & 153 & $\begin{array}{l}\text { Number } \\
\text { Per cent }\end{array}$ & $\begin{array}{l}326 \\
99.7\end{array}$ & $\begin{array}{l}0 \\
0\end{array}$ & $\begin{array}{c}(1)^{* *} \\
0.3\end{array}$ & 327 \\
\hline$M \times N$ & 179 & $\begin{array}{l}\text { Nuniber } \\
\text { Per cent }\end{array}$ & $\begin{array}{c}(1)^{* *} \\
0.3\end{array}$ & $\begin{array}{l}0 \\
0\end{array}$ & $\begin{array}{c}376 \\
99.7\end{array}$ & 377 \\
\hline $\mathrm{N} \times \mathrm{N}$ & 57 & $\begin{array}{l}\text { Number } \\
\text { Per cent }\end{array}$ & $\begin{array}{l}0 \\
0\end{array}$ & $\begin{array}{l}106 \\
100.0\end{array}$ & $\begin{array}{l}0 \\
0\end{array}$ & 106 \\
\hline$M N \times M$ & 463 & $\begin{array}{l}\text { Number } \\
\text { Per cent }\end{array}$ & $\begin{array}{c}499 \\
51.3 \pm 1.1\end{array}$ & $\begin{array}{c}(1)^{* *} \\
0.1\end{array}$ & $\begin{array}{c}473 \\
48.6 \pm 1.1\end{array}$ & 973 \\
\hline $\mathrm{MN} \times \mathrm{N}$ & 3.51 & $\begin{array}{l}\text { Number } \\
\text { Per cent }\end{array}$ & $\begin{array}{c}(3)^{* *} \\
0.4\end{array}$ & $\begin{array}{c}382 \\
47.9 \pm 1.2\end{array}$ & $\begin{array}{c}411 \\
51.7 \pm 1.1\end{array}$ & 796 \\
\hline $\mathrm{MN} \times \mathrm{MN}$ & 377 & $\begin{array}{l}\text { Number } \\
\text { Per cent }\end{array}$ & $\begin{array}{c}199 \\
24.7 \pm 0.8\end{array}$ & $\begin{array}{c}196 \\
24.5 \pm 1.0 \\
\end{array}$ & $\begin{array}{c}405 \\
50.8 \pm 1.1 \\
\end{array}$ & 800 \\
\hline Totals & 1.580 & & 1028 & 685 & 1.666 & 3.379 \\
\hline
\end{tabular}

* This table includes all the previous studies made by the authors (summarized in Amer. Jour. Human Genetics. 3: 179-183, June, 1951) together with the results of the present investigation.

** These apparent exception to the laws of inheritance are due to illegitimacy.

26 - A. Ge. Me. Ge. (III) 
Furthermore, Andresen (1947) has found no exception to the genetic theory involving the mother in more than 20,000 cases of disputed paternity. It is abundantly clear, therefore, that the genetic theory of Landsteiner and Levine is correct, so that the application of the M-N tests in medicolegal cases of disputed paternity is reliable when the tests are carried out by qualified individuals.

Special attention is drawn to the mating $M N \times M N$, since certain investigators have reported an excessive number of children of type $\mathrm{MN}$ in this particular mating. As shown in table 2, among 800 children from $\mathrm{MN} \times \mathrm{MN}$ parents we found 405 of type $\mathrm{MN}$, which is almost exactly the number predicted by the genetic theory. Statistically, therefore, our findings for this mating agree closely with the genetic theory, and it is not necessary to invoke any hypothetical mechanism whereby " the heterozygote is favored by selection ", as suggested by certain workers.

\section{Distribution of the M-N-S Types}

The opportunity is taken here to present some hitherto unpublished data on the M-N-S types in New York City. The tests in question were performed during the years 1949-1952 on 954 professional donors, of whom 394 were also tested for the $S$ factor. As can be seen (cf. table 3 ) the distribution of the three M-N types correspond closely with our previous findings (Wierer, 1943; 1951). The distribution of the three M-N types in the general population can be used to check the genetic theory either by the gene frequency methor or the $\chi^{2}$ method. Ample evidence of this type has already been published (Wiener, 1943), but it may nevertheless be of interest to apply the gene frequency method to the new series of 954 individuals.

Table 3. Distribution of the M-N-S types in 954 individuals (1949-1952)

\begin{tabular}{|c|c|c|c|c|c|}
\hline Type & Number & Percent & Subtype & Number & Percent \\
\hline \multirow[t]{2}{*}{$M$} & 287 & 30.1 & M.S & 88 & 22.1 \\
\hline & & & M.ss & 37 & 9.6 \\
\hline \multirow[t]{2}{*}{$\mathrm{N}$} & 186 & 19.5 & N.S & 27 & 7.0 \\
\hline & & & N.ss & 49 & 12.4 \\
\hline \multirow[t]{2}{*}{$\mathrm{MN}$} & 481 & 50.4 & MN.S & 106 & 26.9 \\
\hline & & & MN.ss & 87 & 22.0 \\
\hline Totals & 954 & 100.0 & & 394 & 100.0 \\
\hline
\end{tabular}

Since under the genetic theory the frequency of two genes may be calculated by the following square root formulae.

$$
\begin{aligned}
& m=\sqrt{\mathrm{M}} \\
& n=1 \sqrt{\mathrm{N}}
\end{aligned}
$$


It follows that

For the present series,

$$
\sqrt{\mathrm{M}}+1 \overline{\mathrm{N}}=1
$$

$$
\begin{gathered}
1 \overline{\mathrm{M}}+1 \overline{\mathrm{N}}=1 \overline{0.3008}+1 \overline{0.1949}=0.5484+0.4414=0.9898 \\
\text { Therefore } \mathrm{D}=1-(\sqrt{\mathrm{M}}+\sqrt{\mathrm{N})}=.0102
\end{gathered}
$$

As Wiener has shown

$$
\text { P.E. }=\frac{0.6745}{21 / \bar{V}}
$$

where $\mathrm{V}$ is the number of individuals examined. In the present case $\mathrm{P} . \mathrm{E}_{\mathrm{D}_{\mathrm{D}}}=.0109$, so that the value of the deviation $D$ is not statistically significant. Accordingly, these results fit satisfactorily with the genetic theory.

The present study on the distribution of the M-N-S types is of interest since there have been only a few such studies previously published. The distribution of the types observed in the present study agrees closely with that reported by Miller et al. (1951) as well as the earlier studies of British investigators. For fuller details concerning the M-N S types, interested readers should consult the recent papers by Sanger and Race (1951), and by Wiener (1952).

\section{Comment}

The investigations carried out in our laboratory during the last twenty years fully support the theory of Landsteiner and Levine that the three M-N types are inherited by means of a pair of allelic genes. In a series of 1580 families with 3379 children, not a single exception to the genetic theory was encountered that could not be explained by illegitimacy, and in 2,000 additional mother-child combinations no contradiction to the theory was encountered. Thus, the M-N types constitute one of the simplest and clearest examples of Mendelian inheritance in man, and the M-N tests are valuable reliable rests in cases of disputed parentage. Irregularities encountered by other investigators, such as an excess of type $\mathrm{MN}$ children in the mating $\mathrm{MN} \times \mathrm{MN}$ can be attributed to chance or to errors in technique caused, for example, by the use of incompletely absorbed anti$\mathrm{M}$ and anti-N sera. Such reports merely serve to underline the importance of permitting only well qualified individuals to perform blood tests in medicolegal cases. Obviously, the raliability of the results of the blood tests is no greater than the reliability of the worker who carries out the examination. An important source of error which is not covered in this report is the existence of variants of the M-N agglutinogens, notably the agglutinogen $\mathrm{N}_{2}$. The qualified expert will be aware of such pitfulls, and will avoid incorrect exclusions of parentage which could result through failure to detect the weakly reacting agglutinogen $\mathrm{N}_{2}$.

Tests for the blood factors $S$ and $s$ would greatly increase the chance of excluding paternity and in that way would increase the value of such examinations. While a number 
of sera of specificity anti-S have been found, only one or two of specificity anti-s have been encountered to date. It is hardly likely that anyone will attempt to apply tests for factor $s$ in a medicolegal case, in view of the lack of availability of the necessary antisera and the delicate nature of the test. The only anti-s serum available (Levine et al., 1951) is of low liter and avidity and can be used only by the anti-globulin method. With regard to the $\mathrm{S}$ factor there is a greater temptation to apply this test, since sera which gives clear reactions by the simple saline agglutination method are available. However, the sera in general are of low titer and avidity, and only a few small studies on the heredity of the blood factor $S$ have been published. Therefore, the medicolegal application of this new blood factor is still premature, and in order to avoid a miscarriage of justice it must be delayed until better antisera are available and more investigations have been carried out.

It should be emphasized that it is not merely the length of time that a blood factor is known which determines whether or not it may be used in medicolegal cases. For example, agglutinogen $\mathrm{P}$ has been known as long as the agglutinogens $\mathrm{M}$ and $\mathrm{N}$, yet tests for agglutinogen $\mathrm{P}$ are not sufficiently reliable for medicolegal purposes. Unlike anti-M and anti-N sera, anti-P sera cannot be readily produced by deliberate immunization of animals, and one must depend on the rare human sera containing natural anti-P agglutinins or on animal sera containing natural $\mathrm{P}$ antibodies. Such antisera, unfortunately, besides being rare are of low titer, specificity and avidity, and in parallel tests discrepancies may occur. Moreover, tests for blood factor $A_{1}$ and $O$ which have been known even longer than $P$ are not sufficiently dependable for medicolegal use. Similarly, in the case of the blood factors $S$ and $s$, what is mainly needed is not time, but methods for preparing antisera of satisfactory specificity, titer and avidity.

\section{Summary}

New data on the heredity of the M-N types in 420 families with 645 children conform precisely with the requirements of the genetic theory of Landsteiner and Levine. To date as many as 1580 families with 3379 children have been tested in our laboratory. According to our experiences, the three $\mathrm{M}-\mathrm{N}$ types are entirely reliable for use in medicolegal cases of disputed paternity, provided that the individual who performs the tests is qualified.

New data on the distribution of the M-N types in 954 individuals are presented, as well as data on the distribution of the M-N S types in 394 individuals. The findings regarding the M-N-S types agree with previous reports concerning their distribution in Caucasoids. The medicolegal application of the M-N-S types is discussed and it is pointed out that more work must be done before the $S$ and $s$ factors can be safely used. What is needed most is methods for preparing anti-S and anti-s sera of satisfactory specificity and avidity. 


\section{References}

Andresen, P. H. (1947). Reliability of the exclusion of paternity after the MN and ABO systems as elucidated by 20.000 mother-child combinations and its significance to the medicolegal conclusion. Acta path. microb. scand., 24: 545-553.

Davidsohn, I., Levine, P., andWiener, A. S. (1952). Medicolegal application of blood grouping tests. J. A. M. A., 149: 699-706.

LANDSTEINER, K, and LEVINE, P. (1928). On the inheritance of agglutinogens of human blood demonstrable by immune agglutinins. J. Exp. Med., 48: 731-749.

Levine, P., Kuhmichel, A. B.,Wigod, M., and Косн, E. (1951). A new blood factor, s. allelic to S. Proc. Soc. Exp. Biol. and Med., 78: 218-220.

Lombard, J. E. (1952). Massachusetts Practice. Adoption. Illegitimacy, and Blood Tests, 958 pp., Boston Law Book Co., Boston, Mass.

Miller, E. B. Rosenfield, R. E., and Vogel, P. (1951). On the incidence of some of the new blood agglutinogens in Chinese and Negroes. Amer. J. Phys. Anthrop., 9 (2): 115-126.

Race, R. R. and SANger, R. (1950). Blood Groups in Man. 290 pp. Blackwell Scientific Publications, Oxford, England.

SANGER, R., and RACE, R. R. (1951). The MNSs blood group system. Amer. J. Human Genetics, 3 : $332-343$.

Schatkin, S. B. (1953). Disputed Paternity Proceedings, 3rd ed., Mathew Bender, New York City.

UNGER, L. J. (1953) Interesting human sidelights and scientific data pertaining to blood grouping tests for non-paternity. J. Amer. Med. Assoc., in press.

WIENER, A. S. (1931). Heredity of the agglutinogens $M$ and $N$ of Landsteiner and Levine. II. Theoreticostatistical considerations. J. Immunol., $21: 157-170$.

Wiener, A. S. (1943). Blood Groups and Transfusion, 3rd ed., 438 pp., C. C. Thomas, Springfield, III.

WIENER, A. S. (1950). Heredity of the Rh blood types. IX. Observations in a series of 526 cases of disputed parentage. Amer. J. Human Genetics, 2: 177-197.

WIENER, A. S. (1951). Heredity of the M-N types. Analysis of twenty years' work. Amer. J. Human Genetics, $3: 179-183$.

WIENER, A. S. (1952). Heredity of the M-N-S blood types. Theoretico-statistical considerations. Amer. J. Human Genetics, 5: 37-53.

Wiener, A. S., and Gordon, E. B. (1951). Repartition des facteurs de groupes sanguins dans une population de New York City, avec une étude spéciale des agglutinogènes rares. Rev. d'Hématol., 6 (1): 45-50.

Wiener, A. S., and VAIsberg, M. (1931). Heredity of the agglutinogens M and N of Landsteiner and Levine, J. Immunol., 20: 371-388. 


\section{RIASSUNTO}

I recenti reperti sull'eredità dei tipi $M-N$ presso 420 famiglie con 645 fanciulli corrispondono esattamente alle esigenze della teoria genetica di Landsteiner e Levine. Ad oggi nel nostro laboratorio furono praticate delle ricerche per un totale di 1580 famiglie con 3379 fanciulli. Secondo i nostri risultati si può ricorrere ai tre tipi $M-N$ nei casi medicolegali di paternità contestata, a condizione che l'operatore possieda le qualità richieste.

Dei nuovi dati vengono presentati sulla distribuzione dei tipi M-N presso 954 individui, come pure sulla distribuzione dei tipi $\mathrm{M}-\mathrm{N}-\mathrm{S}$ presso 394 individui. Le osservazioni sui tipi $\mathrm{M}-\mathrm{N}-\mathrm{S}$ si accordano con i precedenti re. perti che riguardano la loro distribuzione nei soggetti di razza caucasica. Viene trattata l'applicazione medico-legale dei tipi $\mathrm{M}-\mathrm{N}-\mathrm{S}$ e si rileva che è necessario procedere ad ulteriori ricerche prima di poter utilizzare, con totale sicurezza, $\mathrm{i}$ fattori $\mathrm{S}$ e s. Soprattutto appare necessario possedere dei metodi per la preparazione dei sieri anti-S e anti-s di sufficiente specificità e avidità.

\section{RÉSUMÉ}

De nouvelles données obtenues sur l'hérédité des types $\mathrm{M}-\mathrm{N}$ chez 420 familles ayant 645 enfants se conforment exactement aux exigences de la théorie génétique de Landsteiner et Levine. Jusqu'ici des épreuves ont été faites dans notre laboratoire sur un total de 1580 familles ayant 3379 enfants. D'après nos épreuves, nous pouvons compter sur les trois types $\mathrm{M}-\mathrm{N}$ en cas médicolégaux de paternité contestée, à condition que la personne faisant les épreuves possède les qualités requises.

De nouvelles données sont présentées sur la distribution des types $\mathrm{M}-\mathrm{N}$ chez 954 personnes, ainsi que des données sur la distribution des types $\mathrm{M}-\mathrm{N}-\mathrm{S}$ chez 394 personnes. Les observations sur les types $\mathrm{M}-\mathrm{N}-\mathrm{S}$ s'accordent avec les rapports précédents concernant leur distribution chez les Caucasoïdes. On traite de l'application médicolégale des types $\mathrm{M}-\mathrm{N}-\mathrm{S}$, et on signale qu'il faut encore faire plus d'essais avant de pouvoir se servir en toute sûreté des facteurs $S$ et $\mathrm{s}$. Ce qui est le plus nécessaire, ce sont des méthodes pour la préparation de sérums anti-S et anti-s de spécificité et d'avidité suffisantes.

\section{ZUSAMMENFASSUNG}

Neue Angaben über die Vererblichkeit der $M-N$ Typen in 420 Familien mit 645 Kindern, stimmen genau mit den Forderungen der genetischen Theorien von Landsteiner und Levine überein. Bis jetzt wurden 1580 Familien mit 3379 Kindern in unserem Laboratorium untersucht. Unseren Erfahrungen nach, sind die drei $M-N$ Typen vollständig zuverlässig in medizinischen Rechtsfällen bei denen es sich um bestreitete Paternität handelt, vorausgesetzt, dass qualifizierte Techniker bei diesen Untersuchungen verwendet werden.

Neue Angaben über die $\mathrm{M}-\mathrm{N}$ Typen Verteilung in 954 Individuen, und die der M-N-S Typen in 394 Personen werden vorgeführt. Die sich auf die $\mathrm{M}-\mathrm{N}-\mathrm{S}$ Typen bezienden Resultate stimmen mit den vorhergehenden Berichten über ihre Verteilung in Caucasen ein. Die medizinisch-rechtliche Anwendung der M-N-S Typen wird diskutiert. Es wird jedoch klar gemacht, dass eine weitere Untersuchung der Angaben nötig ist, vordem die $S$ und s Faktoren mit Sicherheit angewendet werden können. Am nötigsten braucht man $\mathrm{Me}$ thoden für die Zubereitung von Anti-S und Ant-s Seren einer befriedigenden Spezifität und Avidität. 